Expl Cell Biol. 1976;44:129

\title{
Prefatory Note
}

The papers presented in this number of Experimental Cell Biology are not conference proceedings in the true sense, but a collection of review articles that revolve about a central topic, namely the involvement of the plasma membrane in some basic immunological phenomena. The idea of presenting these articles was mooted by some of those who took part in the advanced EMBO course on the immunochemistry of the cell membrane held at Ravello in July 1975. It need hardly be said that it is no easy task to gather together material for publication after the Diaspora that marks the conclusion of every conference, and this occasion was no exception to the rule. All the manuscripts were not in our hands until the end of 1976. Their updating to this point, however, has been completed.

The Editors

Paolo M. Comoglio

Serafino Zappacosta 